\title{
All Bad: The Biblical Flood Revisited in Modern Fiction
}

\section{Vladimir Tumanov}

Department of Modern Languages and Literatures, Western University, London, ON N6A 3K7, Canada e-mail:vtumanov@uwo.ca

Arcadia: Internationale Zeitschrift

für Literaturwissenschaft

42 (1) 84-97

DOI 10.1515/ARCA.2007.006 


\title{
All Bad: The Biblical Flood Revisited in Modern Fiction ${ }^{1}$
}

\begin{abstract}
:
Modern retellings of the Flood pericope (Genesis 6-8) depend on the age of the targeted audience. Writing for adults, Wolfdietrich Schnurre, Brigitte Schär, Timothy Findley, and Anne Provoost ask whether universal annihilation can be justified. Their criticism of the divine notion that evil is universal and indiscriminate collective punishment is therefore justified, reveals values that are incompatible with those informing the original biblical narrative. However much modernity is aware that myths are symbolic, it apparently cannot assimilate their ethics without a critical reassessment. In this, modern writers rely on the realistic premises of modern novelistic narration. In contrast, modern retellings of the Flood story for children appear to be far more prepared to accept the ancient value system underlying the biblical narrative. Books for younger audiences seem to be much more comfortable with the notion of generalized evil and global punishment than works for adults. This becomes particularly striking in a number of picture books about Noah's ark. The narrative stance of writers ultimately depends on the way they perceive adulthood and childhood.
\end{abstract}

${ }^{1}$ Published article here:

http://www.degruyter.com/view/j/arca.2007.42.issue-

1/arca.2007.006/arca.2007.006.xml?rskey=N9RMJQ\&result=1\&q=The\%20Biblical\%20Flood\%20Revi sited\%20in\%20Modern\%20Fiction 


\section{Introduction}

Notions of good and evil in the Old Testament have to do with collective responsibility. When the deity punishes - as in the case of Sodom (Genesis 19) or the destruction of Judah by the Babylonians ( 2 Kings 25 ) - the punishment often affects not persons but peoples. In one instance, the Flood pericope in Genesis, the punishment extends to all the people: "The Lord saw how great man's wickedness on the earth had become [...]. So the Lord said: 'I will wipe mankind whom I have created, from the face of the earth"' (6:5-6). Because the story of the Flood is a myth, modern sensibility concentrates on its symbolic dimension. To quote J. Campbell, "the point is that, before such-andsuch could be done on earth, this other, more important, primary thing had to be brought to pass within the labyrinth that we all know and visit in our dreams" (29). However, making sense of a biblical myth by merely reading it is very different from what happens when the story is retold in a modern narrative. The fact of retelling a myth makes the mythic, in a way, literal. This has to do in part with the "realistic" origins of the modern novelistic genre and in part with the notion of individual responsibility, which is taken as a given in the post-Enlightenment world. Read against this background, the notion of collective and arbitrary punishment gains a new, "problematic" dimension.

The Flood myth from Genesis seems to have fascinated numerous modern authors who have tried to refashion the diluvian tale for children and adults. A number of these authors tend not to take the idea of wiping out the entire human race for granted. To quote D. Jacobsen, "I am certainly unaware of any text that construes the biblical adventure on the high seas as a completely positive event" (109; this and all further translations from German are mine [V.T.]). This trend is echoed by K. Piehl who points out that already in the late nineteenth century, retellers of the Flood pericope began to imply that "Noah's unquestioning obedience resulted in inexcusable indifference to the fate of the rest of humankind" (42). This essay considers how modern narratives - from the comic to the tragic - put the biblical Flood through the prism of modernity in order to create rainbows with very different ideological color spectra. 


\section{The Comic}

The first part of Wolfdietrich Schnurre's Der Wahre Noah (The True Noah) is a series of whimsical cartoons depicting Noah's experience during the Flood. The second part consists of Noah's diary, which recounts and evaluates the Flood. Despite his righteousness and willingness to do God's bidding, Noah handles the divine wrath with intense skepticism. Schnurre's protagonist unambiguously rejects the death of the animal world: "And anyway, how did He come up with the idea of killing off the animals too? Is clueless flesh really equally guilty? So is the lamb a 'beast' then? And is a pot of chicken broth - a quagmire of sin?" (62) The grounds for this position have to do with a discrepancy in Genesis 6. Even though reference is made to only human evil as the reason for the Flood (Gen 6:5), we read: "I will wipe mankind, whom I have created, from the face of the earth - men, animals, and creatures that move along the ground, and birds of the air" (Gen 6:7). The admission within the biblical text that the deity is prepared to let the innocent (animals) perish with the guilty (humans) easily leads to the next step: if God can destroy one innocent group, why not another? Could there be good humans among the drowned multitudes? Schnurre's Noah ironically implies this possibility: "Even though He has caused much to drown, it was certainly not the principle of groundless punishment" (76).

And as for real human evil, the following observation by Schnurre's protagonist questions not so much divine justice as it does divine logic: "Sure, a paragon of virtue he [man] is not. But hasn't this been known already since Adam's time?" (62). God's failure to grasp human nature is compounded by the divine regret at having created humanity. To quote R. E. Friedman, the notion of "a deity who can regret things that he has done [...] raises interesting theological questions, such as whether an all-powerful, all-knowing being would ever regret past actions" (59). Furthermore, if, as Schnurre's Noah argues, "evil" is part of human nature, why does God bother preserving eight humans? On the one hand, the God of Genesis decides to purify the world since "every 
inclination of the thoughts of [man's] heart was only evil all the time" (Gen 6:5). On the other hand, when the Flood is finished, the Creator announces: "Never again will I curse the ground because of man, even though every inclination of his heart is evil from childhood" (Gen 8:21). Was the Flood pointless to begin with? Schnurre's Noah seems to think so, but Schnurre's God does not.

All of the above would explain why God appears as a rash, childish figure in The True Noah. Noah has to put up with what amounts to a divine tantrum: "Man must have patience to be sure. (Because one thing is clear - the heavens have none.)" (72). Hence, Schnurre's Noah sees something which this immature God fails to grasp, namely that the Flood is overkill, for it will wipe out not just the evil people (to say nothing of the innocent animals) but also Mother Nature: "For example, he'll never again get to smell a freshly mown grain field" (74). This field is part of a greater whole that God considers "very good" as He contemplates all His works on the sixth day of creation in Gen $1: 31$. If God is willing to destroy something which is very good in his own judgment, then perhaps neither His judgment nor He himself is ... very good. At least this is one possible conclusion that one takes away from Schnurre's rather biting dissection of the biblical myth.

Brigitte Schär's "Die Idee des Schöpfers" (The Creator's Idea) is also about Noah's rejection of divine judgment. Upon hearing the Flood plans, Schär's Noah is stunned and does not mince his words:

No human offence could be so grave and great that it would justify the annihilation of all life. And what have the animals done? [...] The world is so wide and marvelous, and the Creator would like to destroy it? Because of an indisposition, a bad mood, a disappointment, an aversion? (50-1)

Like Schnurre's Noah, Schär's protagonist does not challenge God's intentions openly. However, as opposed to what happens in Schnurre's retelling, Schär's 
hero acts upon his critical thoughts. For all his condemnation of God, Schnurre's Noah still does what he is told: he gathers all the animals, goes into the Ark, and shuts the door. The barbarous act is condemned, to be sure, but this turns out to be a merely mental rebellion since God's will is still done. Schär's Noah goes a step further and actually prevents the Flood from happening in the first place.

Noah's entire family gathers for a consultation, votes down God's will, and decides to trick the simple-minded deity. The eight chosen humans in "The Creator's Idea" overwhelm God with practical objections: the animals will eat each other; they will multiply inside their quarters; there will be no escape from animal waste; the Ark will have to dodge mountaintops as the waters recede; when the landing does occur, it will be on a mountainside where many animals and humans might perish without any mountain-climbing abilities; etc. (52-3). This tongue-in-cheek approach relies on the difference between myth and modern narrative. The logic of action and consequence overwhelms the mythological mode where such thinking is beside the point. However, the pragmatism inherent in the rhetoric of God's chosen is but a means to an end in Schär's story. The ultimate aim here is the condemnation of genocide, and the comic "realism" of Schär's text is mobilized for the sake of a modern moral stance.

Schär's deity is morally just as primitive as Schnurre's. In fact Noah's family relies on practical arguments in its attempt to talk God out of the Flood precisely because He appears to be an entirely amoral being: "Noah would have liked to appeal directly to the Creator's conscience. However, Noah knew that in the case of a creator such a thing was impossible" (Schär: 51). Therefore, no one tries to evoke God's mercy in "The Creator's Idea," and in the end the befuddled deity falls for the human ruse: "A world-wide Flood was too huge an undertaking even for Him - the Creator. And much more complex than he had imagined" (53). The simple-minded Creator backs off, cancels the 
Flood and proves that he is just like Schnurre's Yahweh: not much of a planner. To top off her reverse theodicy, Schär adds one more fault to God's character: vanity. Even though He agrees to forget about the genocide, he still makes sure the Flood story is inserted into Genesis (54). This turns the Bible into a fraud and God into a faker. With this image of a stupid, amoral, dishonest and by no means all-knowing God, Schär's story comes to a very unorthodox close.

\section{The Tragic}

The humor inherent in Schär's and Schnurre's light-hearted approach goes a long way to downplay the potential tension created by the questioning of something as fundamental as divine justice. This questioning occurs, however, much more directly in two novels that deal with Genesis 6-9 in dark, macabre terms: Timothy Findley's Not wanted on the Voyage and Anne Provoost's In the Shadow of the Ark. Whereas Schär and Schnurre recreate the Flood story as if it were just a fairy tale (hence their tongue-in-cheek style), Findley and Provoost generate a vivid picture of horrors that is as verisimilar as in any modern account of human suffering.

As in Schär's and Schnurre's texts, the Flood is discredited in Findley's novel through the presentation of an imperfect God. Findley's Creator turns out to be - paradoxically - not divine, which undermines any justification of the Flood to begin with. Emma, Japhet's wife, meets Yaweh and sees little more than a senile old man: "Her Lord Creator was a walking sack of bones and hair. She also suspected, from His smell, that He was human" (Findley: 66). God finally proves that he is indeed human by dying just before the Flood (112), thereby forsaking any right to the kind of supramoral heavenly prerogative that justifies the Flood in Genesis. N. Cohn points out that in sending the Flood, the biblical deity acts according to the model of an absolute ancient monarch: "Not to be questioned, not to be reasoned with, not even to be understood, in solitary and terrifying majesty he decides the perdition or salvation of the world" (18). This 
kind of stance cannot be contaminated by imperfections reminiscent of those upon whom the superior being acts. Thus, if it turns out that the ruler is ontologically "one of us," his authority crumbles.

Before he dies, Findley's God gives away the fallacy of his less-than-perfect judgment. To justify the revulsion that Yahweh feels toward the world in Not Wanted on the Voyage, He hurls a litany of accusations at humanity: "Pride and lechery; envy and anger; covetousness; gluttony and sloth are everywhere, all that One sees!" (89) However, God then proceeds to invalidate (albeit inadvertently) the idea that evil is "all that One sees" by saying: "Men women - children: all are subject of corruption" (89). Given the axiomatic assumption of children's innocence, Findley's God falls into his own trap of overgeneralization. In Genesis, the question of children drowning along with the evil adults is conveniently overlooked, but it begs to be answered in a novel where the details of reality must be accounted for. In Findley's text, all references to the universality of human corruption are themselves corrupt from this point on. And this explains the title of the novel: Not Wanted on the Voyage. Its heroes are the villains of Genesis, i.e., the people, even children, who have "grieved" God.

To be sure, there is evil in the world of Not Wanted on the Voyage: "According to the itinerant workers who said they had seen it with their own eyes, the Festivals of Baal and Mammon were getting out of hand. They said that human sacrifice had been approved and chowder had been made of the meat" (23). To this is added Yahweh's own report of having been attacked everywhere he goes and even assassinated (70). The picture of a depraved humanity is made even more somber by Japhet's experience of having been nearly eaten by a group of cannibals $(78,81)$. In fact, at first it seems that only God's above-mentioned lapse about childhood corruption weighs against the charge of universal evil. However, as the novel progresses, we encounter people outside of Noah's family to whom God's accusations do not apply. 
This group is represented by Emma's family, which epitomizes tolerance and kindness. Emma's father has a "kindly face you could never forget" (Findley: 116); he holds Emma "just as he must have held her as a child" (117). Her brothers are hard-working, gentle giants who dote on Emma, and we are told that "she loved her brothers and missed them dreadfully" (116). Emma's mother is presented in similarly flattering terms (117). But what underscores more than anything the moral dignity of this family is the way they treat Emma's retarded sister Lotte. Instead of killing her, as is done by Noah in the case of his own retarded son, Emma's parents raise Lotte and hide her from all danger (148-49). The implication is that there are many more people like Emma's family because a very large group of workers, including Emma's father and brothers, toils to build the Ark (119-121). Hence, the prospect of these people's death appears as an appalling crime rather than the cleansing action in Genesis: "Emma did not know that her father and mother, her brothers and Lotte, were to be drowned. Mrs. Noyes who did know could not bear to think it was true" (Findley: 119). It is therefore understandable that Findley's Flood constitutes genocide in the modern sense of the term and this is referred to in no uncertain terms as "the holocaust on earth" (110). D. Jefferess associates the Flood in Not Wanted on the Voyage with National Socialism: "Just as the Nazis sought to heal European society from the disease of those deemed less than human [...] so too Yahweh cleanses the Earth of its ills [...] through the Flood" (146-47; cf. C. Demousselle: 47, 50).

Like Schnurre and Schär, Findley addresses the question of the animals. However, whereas the former authors refer to the beasts merely as the innocent "collateral damage" of divine action, Findley dwells on the animal realm in order to magnify God's moral failure. To begin with, a number of the protagonists in Not Wanted on the Voyage are anthropomorphized animals. Mottyl the blind cat, who is slated for destruction, strikes us as a thoroughly positive character who respects all life and deplores the murder of the animals as she awaits the Flood. She tries to save the lemurs Bip and Ringer by urging 
them to board the Ark (144). Mottyl shares food with a Vixen even though the latter is trying to hunt the cat in the panic that precedes the Flood (141). Most of all, Motyll's concern for her lost kitten demonstrates loyalty and devotion: "By the end of four or five hours of continuous searching, her brain was frantic but her body almost immobilized from exhaustion. Her drops into the resting position were becoming more and more frequent - until finally she could barely rise to make the journey back to her own corridor" (316).

Another animal worthy of admiration is Crowe, a bird that sacrifices its life to free the prisoners in the hold of the Ark (Findley: 327). The long list of positively portrayed animals includes the naïve sheep who sing the praises of God even as the deity plans their demise (67-69), and the unicorn who is butchered by Noah (264-66). Ultimately, the greatest impact is achieved by the account of the manner in which the forest's inhabitants perish: "Squirrels, rabbits, monkeys, moles and a dozen kinds of birds could find no place to hide - and their cries were everywhere - and the stench of blood and offal" (145). Findley creates the impression that the innocent animals are just as worthy of pity as the innocent humans - all victims of injustice and indiscriminate murder. As Mrs. Noyes, Noah's wife, contemplates the Flood from the Ark, her thoughts point to the interconnectedness of all life forms killed by God:

There below her was all the world [...]. There were the farms - and all the white stone buildings [...] and the tumbled fences over which and through which all the drowned cattle and all the drowned goats had finally managed to find their way [...] and villages and all the houses where all the people had lived, lying emptied now of noise and commerce and community (342-3).

It is particularly the word "community" that evokes the notion of terrible loss rather than the idea of purged evil. Community is the embodiment of the social, i.e., the opposite of "evil." In all cultures the concept of community denotes something to be preserved rather than swept away. 
Anne Provoost's In the Shadow of the Ark is narrated by a teen-age girl called Re Jana. She is not meant to be saved from the Flood but befriends Noah's son Ham and ends up rescued against all odds. Whereas Findley stresses divine injustice by positing a very imperfect deity, Provoost keeps God as a character out of the picture altogether. Only the divine decree is questioned through $\operatorname{Re}$ Jana's point of view: "I was thinking mainly of the many who would die. Ham had told me about the god who was going to kill all those without principles" (110). Findley and Provoost consider "those without principles" in different ways. Since there is indeed a great deal of human depravity in Not Wanted on the Voyage, Findley goes along with Genesis 6 up to a point - but only to argue that "two wrongs don't make a right," and, no matter how widespread evil may be, there is always some goodness somewhere worth preserving. Provoost, on the other hand, proceeds from the assumption that antediluvian humanity is not especially corrupt to begin with. Thus, as Re Jana considers all those helping to build the Ark, she says: "I assumed that everyone I knew in the yard would be saved. They were all people of good will, and if indeed they had sinned in their lives, the sins had only been lapses, not something that was part of their nature. And they were not evil" (113).

Although Re Jana keeps meeting ordinary people, she does acknowledge at first that some evil-doers exist. Naïvely assuming that God will only punish those who deserve it, she asks Ham: "What happens to those for whom there is no room in the ark and who are not depraved? Will they be given huts on stilts? Are you building a settlement for them in the hills?" (122). Gradually the truth becomes evident, and the sheer barbarity of the situation becomes apparent to Provoost's shocked heroine:

And who were the depraved that had to be killed? Were they the men and women who sang at night near the big tents, the foremen with their dancing wives, the warriors carrying swords who wandered about chewing herbs and saying they could see themselves walk? Were they the women of the family farther along who threw their food scraps onto our path? The 
man who staggered drunkenly across our little fields at night? The child who had eaten a piece of my sponge? (112)

Here too the question of children slated for death serves as the ultimate "j'accuse" of the novel. The reference to the sponge-eating child is placed strategically at the end of the paragraph in order to create a climax of injustice. Re Jana herself tries to rescue a child called Put whose touching innocence is underscored throughout In the Shadow of the Ark. In the end, Put is saved as a stowaway on Noah's ship, but he emerges from the Ark as a deeply traumatized shadow of a child who has forgotten human language and can only "growl like an angry monkey" (352). Put survives in order to become a silent living reminder of all the children who drowned. His mental scars represent a call to grief over something irreparably lost.

As the time of the Flood nears, Re Jana and her father constantly care for her paralyzed mother, washing her, grooming her, feeding her, and keeping her comfortable. Ham, who is supposed to be one of the righteous, cannot understand this morality at first: "Why does your father keep her alive? [...] Why drag along a woman who does not move when your order her?" (44) This conflict is reminiscent of the way the retarded Lotte is handled by Emma's family (in contrast to the murder of Noah's retarded son) in Findley's novel. Yet again associations with Nazi policies of euthanasia are difficult to avoid, especially given the division of the world into the "righteous" and the rest (cf. Provoost: 66). Re Jana points out the moral weakness of the "righteous" position by saying to Ham: "If you were righteous, you would now be giving up your places. You would be giving them up to the children, the lame and the feebleminded! What do they have to atone for?" (127) Ham's primitive ethics suggests that the morality behind the entire Flood project is flawed, and a terrible injustice is about to take place. 
Eventually Ham is transformed through contact with Re Jana. This is expressed symbolically by Re Jana's repeated washing of Ham, taking off layers of "ethical blindness" until she makes him "unrighteous." When Re Jana washes in turn Noah's sons Shem, Ham, and Japhet, the response of each brother is laden with moral meaning. Shem merely giggles, Japhet cannot seem to relax, but Ham comes alive under Re Jana's cleansing touch: "As I rubbed his arms, I could feel his pulse beat [...] I could see him repressing an urge to close his eyes. His breath was not wheezy, he was breathing more freely and lightly than before" (64). Ham comes to reject the Flood and Noah's obedience, betraying his father in line with Genesis where Noah curses Ham. However, the curse is motivated very differently in Provoost's novel. In Genesis 9:20-23 Ham shows disrespect to Noah by looking at his father's nakedness as Noah lies there in a drunken stupor. In Provoost's novel, Ham says upon seeing his naked and intoxicated father: "He drinks so he does not have to see what he has brought about" (362). Thus, Provoost's Noah curses Ham not for mere disrespect toward his father but for condemning the injustice of the Flood and God's flawed notion of righteousness.

As Re Jana considers God's select group emerging from the Ark, she sums up God's failure: "This was them, the chosen, the beginning of the new humanity. No one had changed. Taneses was as greedy as ever, Zedebab still vacuous, Neelata just as full of hatred for her mother, Shem still fanatical and Japheth still persuaded of his own inferiority" (362). Like Schnurre, Provoost evokes Genesis 8:21 where God admits that "every inclination of [man's] heart is evil" even after the Flood. However, a sense of hope emerges through the birth of Ham's and Re Jana's child soon after the landing of the Ark (Provoost: 355). The survival of Re Jana's baby stands for the survival of tolerance against all odds in the angry sea of brutality and prejudice. At this point it seems that Noah and his brutal God have nothing more left to say. 


\section{Entertaining the Young}

When Genesis 6-9 is retold for a younger audience, we notice a shift in the attitude toward the injustice of the Flood. The main issue is the charge of universal evil and the collectivist approach to guilt in the biblical text. What texts for adults appear to reject seems not as unacceptable in the retellings of the Flood story intended for teenagers and, especially, for young children. Barbara Cohen's Unicorns in the Rain, a novel for adolescents that was banned as being too controversial for its genre, is an interesting example. The heroine here is a teenage girl called Nikki who lives in a world like our own but one where corruption and evil appear to be truly universal. Social bonds have collapsed as Nikki's own dysfunctional family demonstrates. Nikki lives with a mother who has many boyfriends and does not care about her daughter; she tries to get rid of Nikki whenever she can $(4,17)$. Everyone, including Nikki, is armed because robbers lie in wait everywhere (27). Nikki witnesses an armed assault as a gang of youths beats up an old couple merely for a thrill: "It wasn't money they were after. They were just out for a good time [...] Three or four other passengers, who had gotten off the train with us and were also waiting for rides, stood impassively under the porte-cochere, watching" (2930).

To make sure the reader does not assume that evil is anything less than pandemic, Cohen includes the following headlines from a newspaper that Nikki reads: "Famine toll reaches two million. Surplus grains rot in silos. Bankrupt nations lack funds for purchase ... 18,726 dead and wounded in war's 203 month ... Prime minister held for millions in ransom" (69). However, no one cares because everyone is on drugs: "After all, ninety-nine percent of the population is stoned seventy-five percent of the time" (24). In all this depravity there is one righteous group: modern-day Noah and his family. They take Nikki in, hoping that she would become Hamilton's (Ham's) wife and join them on the Ark which they have built. The question that Unicorns in the Rain tries to answer is whether or not the Flood can be justified even if God's sweeping 
condemnation of humanity from Genesis $6: 5$ is correct. This differs greatly from the texts for adults cited above, where the very idea of universal evil is rejected outright. Thus, the ethical issue considered in Cohen's novel is not generalizations as the basis of prejudice but rather the nature of mercy.

Nikki is confronted with this problem when she hears what Noah's family has to say about the rest of the world. In response to Nikki's concerns regarding the morality of the upcoming Flood, Noah assesses the people out there as follows: "They don't want to be saved. They don't want the world to be any different from what it is" (106-107). This incredible judgment turns out to be justified. Even Richie, Noah's loyal and honest farm hand, appears to be content with the state of society and refuses to join the crew of the Ark $(105,109)$. "As for all the rest - every one of them," says Noah's son Sam (Sem), "they'd as soon see you drown. That's the difference between them and us" (109-110). However, Nikki's reaction to this black-and-white reasoning indicates a higher level of ethical sophistication. Even though she cannot help but accept the universality of evil, she is still unable to abide by God's solution. Recalling all the depraved people she has encountered, she thinks of "Poor Stash. Poor Richie. Poor fat lady. Poor Ken. Poor unicorns. Poor Grandmother. Poor Mama" (137). She does not consider herself as part of Noah's family: "I belong with the other people" (145-146).

Nikki rejects the harshness of the biblical deity who lacks the capacity for forgiveness in Genesis 6-9. As a result, she is incapable of believing in God. "I don't want to sound dumb or anything, but who's this lord?" she asks Noah, "I thought all those old superstitions had died out completely" (52-53). Although Noah is shocked by her atheism, he admits that religious belief is often the antithesis of critical thinking: "You can question, Nikki, because you don't believe. A believer can only accept" (122). Even as she goes on board the Ark, Nikki has trouble accepting a merciless God (163). Like Re Jana in Anne Provoost's novel, Nikki brings to the new world that urge to doubt and question 
that humanity will need in order to sustain a balance between justice and compassion.

Despite Nikki's critical attitude, Unicorns in the Rain sends an ambiguous message. By not rejecting the charge of universal evil from Genesis 6:5, Cohen allows for the notion of moral homogeneity and leaves the door open to genocidal thinking. Her novel does not fit P. Nodelman's assertion that such a collectivist approach is foreign to modern children's fiction:

The major thing we'd like children to believe is [that] [...] each of us is a unique individual with unique tastes and interests, entitled to the freedom to make choices. [...] Not surprisingly countless children's books and movies reinforce the message that we need to respect and to treasure the ways in which we are different from each other (92).

However, Cohen's novel is not the only exception to the trend outlined by Nodelman. When we go down the age scale and consider children's picture books about the biblical Flood, we find a definite tendency to question neither the universality of human evil nor the morality of the divine punishment.

P. Dickinson's City of Gold is somewhere between a picture book and a work for older readers because longer passages in rather small print alternate with illustrations on almost every other page. In this compendium of biblical stories, the Flood pericope is retold without any verbal questioning of divine justice: "Then died the corrupted men - and the corrupted beasts also, the winged lions and the sphinxes, the dragons and the unicorns" (24). However, the accompanying illustration tells a somewhat different story: people and animals cling to a rock in desperation as the waves are about to engulf them. Next to a woman we see a tiny baby holding on for dear life - clearly not for long (25). If, as argued above, any reference to the death of children among the presumably corrupt adults undermines the logic of divine justice in a modern text, the picture in Dickinson's book undermines the narrative which is silent on the matter. 
The same illustration also makes an interesting statement about the animals that die in the Flood. All the "real" animals on the rock are predators: a lion, a tiger and a giant snake. The basis for linking predation with evil may be sought in Gen 9:4-5 where God tells Noah right after the flood: "And for your lifeblood I will surely demand an accounting. I will demand an accounting from every animal. And from each man, too, I will demand an accounting for the life of his fellow man." According to J.P. Harland, the logic of Genesis suggests that "there is no reason why the animals should not be seen as having some moral responsibility given the statement of $9: 5$ that animals are liable for punishment" (31). Since "lifeblood" is the issue, Harland goes on to suggest that the animals are drowned in the Flood for predation (31). Just as Genesis avoids dealing with the uncomfortable fact of having herbivores drown along with the lions and tigers, so too in Dickinson's text no herbivores are pictured in the above-mentioned illustration. However, ultimately the death of the animals in Genesis is incidental, and attempts to justify it stand on weak ground. Therefore, the depiction of predators in Dickinson's story is a visual rhetorical device intended to legitimize the death of corrupt humans through their association with violent beasts. Only the baby serves as a reminder that the punishment may be questionable.

In genuine picture books the trend is uncritical, for no mention is normally made of innocent Flood victims, and the collectivist ethical values informing the biblical narrative are accepted as self-evident. In B. Reid's Two by Two we find a straightforward approach to the moral state of antediluvian humanity: "Way back in the olden days / People turned to evil ways. / They spoiled the world with greedy plots, / Dirty deeds and nasty thoughts. / God was mad, and with a frown, /Said, 'Wash it clean! Let them drown!'" (1). J. Pinkney's Noah's Ark adopts the same simple approach (1) while other books - e.g., P. L. Gouch's Noah (4) or T. de Paola's Noah and the Ark (1) - barely mention the rest of humanity, focusing instead on Noah and his task. B. Brenner deals with total corruption more emphatically in Noah and the Flood: "Now there was a time 
back in the Bible days when the whole world had turned bad. Folks were mean and evil. They cheated and stole. They broke every one of God's laws." In the next section of text, which is separated from the previous passage by a space, we read: "Every one, every one - they broke God's laws, every one" (1). The isolation of the last sentence from its context and the reliance on rather ambiguous syntax yields a curious twist. Although "every one" ostensibly refers to God's laws, one can also read it as pointing to the bad people on earth.

Some picture-book authors come up with entirely new reasons for the slaughter of humanity. In M. Bolliger's Noah and the Rainbow God's decision to have Noah build the ark appears completely unmotivated: the Creator mentions neither human evil nor the upcoming Flood. When Noah is building the ark, people gather and start laughing at him: "Their scorn did not trouble Noah. But God was angry with them because they did not fear Him, and because they laughed" (5). It is puzzling enough that this lack of respect seems to be reason enough to wipe everyone out, but it is even more striking that God's apocalyptic plans appear to precede the evidence of human evil. Still more amazing is the justification of the Flood in L. Graham's God Wash the World and Start Again: "God see mens [sic] what grow like trees" (9). Since no other motivation for punishment is given, humans appear to deserve annihilation because they have grown to a prodigious size! Graham conflates two elements in the Genesis narrative: the appearance of giants (nephilim) on earth (Gen 6:4), and the reference to human evil (Gen 6:5).

Michael Flanders' Captain Noah and his Floating Zoo, stands out especially because it presents the drowning of humanity in almost caricatural terms. First people welcome the rain, then they start panicking when too much water comes down, and finally they drown: "Glug! Glug! Glug!" (14). Although the accompanying illustration shows people desperately trying to escape drowning, the interjection "glug" lends the primeval holocaust a cartoon-like character which rules out tragic implications. In some of the other above-mentioned 
picture books we also find illustrations of drowning people; however, in the absence of commentary or an image like Dickinson's drowning baby, God's assertion of universal human depravity remains unchallenged. As K. Piehl writes: "the majority of Noah's ark picture books follow the Genesis emphasis on obedience and maintain Noah's silence" (45).

\section{Conclusion}

How is one to explain that the younger the targeted audience the less critical the retellings of the biblical Flood pericope appear? Perhaps adults - including writers, publishers, parents and librarians - assume that children are inherently optimistic: "Because we tend to assume that children are ignorant of pain and suffering and thus see the world without consciousness of the cruelty or suffering within it, we also assume that children's literature expresses that innocent and optimistic way of looking at things" (Nodelman: 164). Is the young child capable of dealing with discourse about a world where the very keeper of order - God Himself - may be incompetent or cruel? H. Bosmajian's examination of children's books on the Nazi Holocaust echoes P. Nodelman's above-cited assessment: "Children's literature is a medium that spares both the author and the child reader as the official text of the story sublimates and disguises a personally or socially complicated subtext" (Bosmajian: xiv). Bosmajian calls this "protective censoring."

It could be argued that the picture book genre remains more faithful to the spirit of the myth and its symbolic connotations, as well as to the values of the age that produced the Flood story. Picture books would offer thus a more "authentic" mythological experience, and the child-reader would thereby be placed in a position much closer to that of the audience for which the biblical text was presumably intended. Such authenticity does not appear to be the primary objective of authors writing for an older audience. They use the Flood myth as a vehicle for affirming modern values; the myth becomes in their 
treatment an anachronistic metaphor for something quite distant from its original ethos. The difference between these two perspectives is formulated by C. J. Winters and G. D. Schmidt:

It is the task of all retellers of biblical tales to erase familiarity, to create a meaningful distance so that the stories may be told with power and meaning. But even as he or she defamiliarizes, the reteller of a biblical tale must still tell the authentic tale, so that the story's ethos - its basic meaning and context - are preserved. At times these two impulses distancing and preserving - vie with each other (163).

Which of the two impulses wins out in a particular work will depend on the meaning attached to adulthood and childhood.

\section{Works Cited}

Bolliger, Max. Trans. Clyde Robert Bulla. Noah and the Rainbow, New York: Thomas Y. Crowell, 1972.

Bosmajian, Hamida. Sparing the Child and the Unspeakable in Youth Literature about Nazism and the Holocaust, New York: Routledge, 2002.

Brenner, Barbara. Noah and the Flood, New York: Bantam Doubleday Books for Young Readers, 1992.

Campbell, Joseph. The Hero with a Thousand Faces, Princeton, NJ: Princeton University Press, 1973.

Cohen, Barbara. Unicorns in the Rain, New York: Atheneum, 1980.

Cohn, Norman. Noah's flood: the Genesis story in Western thought, New Haven: Yale UniversityPress, 1996.

Demousselle, Corinne. "Antifascism and Characterization in Timothy Findley's Not Wanted on the Voyage." The Guises of Canadian Diversity. Ed. Serge Jaumain and Marc Maufort, Amsterdam: Rodopi, 1995.

Dickinson, Peter. City of Gold, London: Victor Gollancz, 1980.

Findley, T. Not Wanted on the Voyage, Toronto: Viking, 1984. 
Flanders, Michael. Captain Noah and his Floating Zoo, Indianapolis: BobbsMerrill, 1972.

Friedman, Richard E. Who Wrote the Bible? New York: Summit Books, 1987. Gauch, Patricia Lee. Noah, New York: Philomel Books, 1994.

Graham, Lorenz. God Wash the World and Start Again, New York: Thomas Y. Crowell Company, 1946.

Harland, P. J. The value of human life: a study of the story of the flood (Genesis 6-9), Leiden; New York: Brill, 1996.

Jacobsen, Dietmar. "Nacherzählen - Neuerzählen - Umerzählen. Aspekte des Umgangsmit der Sintflutgeschichte in der deutschen Gegenwartsliteratur." In: Dietmar Jacobsenet al. (Ed.). Kreuzwege. Transformationen des Mythischen in der Literatur, Frankfurt am Main: Peter Lang, 1999.

Jefferess, David. "A Pacific (re)reading of Timothy Findley's Not Wanted on the Voyage." Essays on Canadian Writing 72 (Winter 2000): 138-57.

Nodelman, Perry. The Pleasures of Children's Literature, White Plains, NY: Longman, 1996.

Paola de, Tomie. Noah and the Ark, Minneapolis, MN: Winston Press, 1983. Piehl, Kathy. "'By Faith Noah': Obedient Servant as Religious Hero." Lion and the Unicorn 13 (1989): 41-52.

Pinkney, Jerry. Noah's Ark, New York: SeaStar Books, 2002.

Provoost, Anne. In the Shadow of the Ark. Trans. John Nieuwenhuizen, New York: Arthur A. Levine Books, 2004.

Reid, Barbara. Two by Two, Richmond Hill: Scholastic Canada, 1992.

Schär, Brigitte. "Die Prufung / Die Idee des Schöpfers." In: Friedrich Vilshofen (Ed.). Und Gott sprach ... Biblische Geschichten neu erzäh/t, Munchen: dtv, 2003.

Schnurre, Wolfdietrich. Der wahre Noah, Zurich: Arche, 1974. Winters, Carol J. and Gary D. Schmidt. Edging the Boundaries of Children's Literature, Boston: Allyn and Bacon, 2001. 